\title{
Book Review: Local Government in a Global World: Australia and Canada in Comparative Perspective
}

Commonwealth Journal of Local Governance

Issue 7: November 2010

http:/lepress.lib.uts.edu.au/ojs/index.php/cjlg

\section{Claudia Scott}

Victoria University of Wellington, New Zealand, and The Australia and New Zealand School of Government Australia

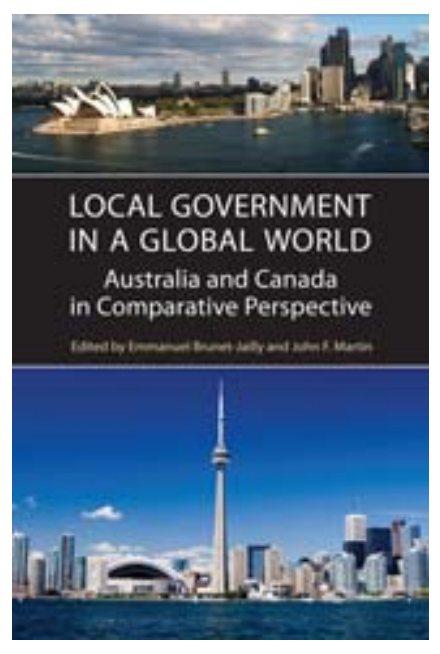

\section{BOOK REVIEW: Local Government in a Global World: Australia and Canada in Comparative Perspective}

Edited by Emmanuel Brunet-Jailly and John F. Martin (University of Toronto Press, Toronto, Canada, 2010)

This book compares reform trends in Australia and Canada's local government systems over the past two decades, with attention to the impact of globalization on local governments, their bureaucracies, and local democratic accountability. ${ }^{1}$ Local governments in Australia and Canada show striking resemblances in relation to history, development, and contemporary issues. This reflects that in both countries, local governments remain an instrument of the states and provinces.

The exploration of the connections between globalization and local government is timely given the importance of international influences on the economic, social and

\footnotetext{
1 The impetus for the book followed from an Institute of Public Administration of Canada (IPAC) sponsored conference on municipal performance and measurement practices featuring experts from Canada and Australia. The IPAC commissioned the publication as part of its series on public management and governance.
} 
environmental challenges facing governments. For the local governments discussed in the book, and for many others, economic and fiscal constraints have reduced the sector's ability to meet community expectations while also responding to growing competitiveness across jurisdictions. These pressures have highlighted the benefits of encouraging regional and local differentiation, and giving prominence to 'place' in policy and management designs and practices.

The phrase 'glocalization' reflects the trend in which the local communities are becoming more influenced by global trends, while at the same time seeking to differentiate their regions and localities. Is this phenomenon a sign of an overloaded policy agenda which seeks to simultaneously reap the benefits of globalization while also furthering regional and local distinctiveness? Such issues deserve more attention by both academics and practitioners and more widespread debate about the appropriate balance between these competing pressures.

Both Australia and Canada have experienced increasing rates of urbanization over recent years and employ diverse policy and management practices in metropolitan and urban as opposed to rural areas. Canada's population of over thirty-two million is organised into ten provinces, three territories and 3,700 municipalities. Australian's population of over twenty-one million has six states and two territories, but only 600 local councils. The smaller number is the result of rationalisation in some states and territories including, most recently, in Victoria and Queensland. An important difference relates to the wider range of services provided by Canadian governments, and accounts for the fact that local government revenues are 10\% of GDP in Canada but only 6\% in Australia. In the two countries federal and state/provincial governments make up 15-20\% of revenues.

Canada and Australia make interesting comparisons and share many similarities, but differences also exist. This relates, in particular, to the fact that local governments are part of a federal system, and the way they operate on a day-to-day basis is governed by legislation set at the state or provincial levels. Australian local councils have never offered the wide range of functions carried out by municipalities in other Anglo-based nations. Primary responsibility for policing, health, public housing and education in Australia has always been the responsibility of state governments from the country's inception in the nineteenth century until after the Second World War, when municipalities became pre-occupied with physical infrastructure requirements such as 
building roads, bridges, sewerage systems etc. From the 1970s, the sector's profile shifted to the development of facilities for communities.

In both countries, state and provincial governments dominate, on a day-to-day basis, how local governments operate. Sources of funding for local government consist of propertybased funding, local fees and charges, and revenue sharing with higher-level governments. Canadian communities benefit from access to a local goods and services tax. In Australia, a goods and service tax is levied by the federal government and the proceeds are distributed to state governments, though transfers to local government are made by both Commonwealth and state governments.

The pattern of local government reform is by no means consistent across jurisdictions, and strategies are sometimes adopted which involve different policy and management approaches in urban, as opposed to rural, areas. While there are some signs of changes, which support a strengthening of local government and community governance, other measures appear to give attention to gaining higher levels of performance and accountability of local government. In both countries, there is sometimes reluctance to decentralise or devolve functions and funding to local government units. Tight fiscal climates can lead to unfunded mandates for/to local government, a phenomena known as 'cost-shifting' in Australia, and ‘downloading' in Canada.

This reflects the current nature of intergovernmental relationships in both countries, and may also provide the explanation as to why there appears to be somewhat limited evidence that local communities have influenced and adapted to globalization per se. While there has been substantial reform in both countries, the specific drivers of this are often unclear, and change is often underpinned by particular ideologies; for example, New Public Management approaches which have been adopted in certain Australian jurisdictions.

Editors Emmanuel Brunet-Jailly and John Martin provide a sound rationale for their selection of Australia and Canada as the basis for comparative analysis. They consider the phenomena of globalization, drawing on relevant literature and identify the linkages and impacts on policy and practices in local governments. The analysis and discussion of reform and globalization influences draws on contemporary literature, and is organised into four themes: citizen participation and governance in local decisions; the 
restructuring and reforms of local governments; the usage of performance measures and management systems in the administration of local governments and; the relations of local governments with higher level governments. Each theme is treated in a set of paired chapters which consider individual country experiences coupled with cross-country comparisons. In the concluding chapter, the editors draw together the discussion of country experiences in the context of the four identified themes and provide many interesting insights.

Chris Aulich (Chapters 2) and Susan Phillips (chapter 3) explore aspects of community engagement and governance in Australia and Canada respectively. Participatory governance is at an early stage in both countries and, despite various attempts at reform including modernisation, there appears limited change in the power nexus between state and local governments, and no new functions have been introduced in Australia and the evidence to support stronger participatory democracy is weak.

The Canadian experience in this regard is more complex and there appears to be the emergence of participatory governance in large metropolitan jurisdictions in Canada. The authors cite evidence that New Public Management has influenced the design features of reforms in Australia, but with much less emphasis in Canada.

In Chapters 4 and 5, Neil Marshall and Andrew Sancton explore patterns of restructuring and reform in Australia and Canada. In Chapter 6 Louise Kloot and John Martin compare theory and practice in Australian local government performance management, and offer a discussion and analysis of trends, competing views and current and future challenges. In Chapter 7, similar issues are addressed by Carol Agocs and Emmanuel Brunet-Jailly in the Canadian context. While the authors have adopted different methodological approaches to the topics, they reach similar conclusions with respect to the nature of future challenges relating to local governments.

In Chapters 8 and 9 Graham Sansom and Catherine Graham review the literature and discuss issues and questions which underpin debates about intergovernmental relations in Australia and Canada. The authors suggest that the two countries are noticeably different in their approaches. For example, Australian local governments seem to be involved in many formal policy processes relating to national and regional policy issues. This contrasts with Canada where there is more limited engagement in policy-making at the 
provincial and federal levels. The countries also differ in that policy settings are more uniform across municipalities in Australia, whereas in Canada the largest municipalities seem to be set apart.

In the final chapter the editors discuss the key drivers and influences on policy and management practices within the local government sector. They revisit research questions and report on international literature and on policy and management trends, and comment on the importance of global (as opposed to the national and local) influences on local government reforms. The magnitude and influence of globalizing trends on local governments in both countries has been less than anticipated by the editors, though the result reflects of the dominance of national and regional policy settings on local government practices.

Local Government in a Global World is very accessible to practitioners and academic audiences. A distinctive and valued feature of the book is its specific attention to local government trends and the emphasis given to a local government perspective on roles and relationships with state/provincial and federal levels of government.

The discussion of various theories surrounding governance and reform trends in the two countries offers useful insights on specific country experiences, as well as broader trends and developments in the sector.

The editors and authors provide valuable perspectives for those seeking more effective ways to enhance the contribution of local governments to the sustainable development of communities. Moreover, the growing influence of 'place' in policy and management practices suggests untapped potential for local governments to make an enhanced contribution to achieving desired outcomes at federal and state/provincial levels, as well within local communities. 